\title{
Increases in ovulation rate in lupin-fed ewes are initiated by increases in protein digested post-ruminally*
}

\author{
M. B. Nottle, P. I. Hynd, R. F. Seamark $\nmid$ and B. P. Setchell \\ Department of Animal Sciences, Waite Agricultural Research Institute, The University of Adelaide, \\ Glen Osmond, South Australia 5064, Australia; and †Department of Obstetrics and Gynaecology, \\ The University of Adelaide, Adelaide, South Australia 5001, Australia
}

\begin{abstract}
Summary. Parous Merino ewes were maintained outdoors in feedlots during the beginning of the spontaneous breeding season and fed a maintenance ration of wheaten hay. For 14 days, ewes in each of 4 groups $(\mathrm{N}=40$ /group) were given supplements of lupin grain or formaldehyde-treated casein and/or wheat starch. These were calculated to supply equivalent amounts of protein post-ruminally and/or digestible energy. Supplementation with lupin grain significantly increased ovulation rate by $37 \%$ by increasing the proportion of ewes with two ovulations. Similar increases in ovulation rate were achieved by increasing the supply of digestible protein post-ruminally in the casein and casein + starch-supplement groups. Increasing the intake of digestible energy separately in the starch-supplement group did not increase ovulation rate. It is concluded that increases in ovulation rate in ewes fed a lupin supplement are the result of significant increases in the amount of protein digested post-ruminally.
\end{abstract}

Keywords: lupin grain; supplementation; ovulation rate; sheep

\section{Introduction}

Increases in ovulation rate in ewes given supplementary feeding of lupins are thought to be initiated by increases in protein digested post-ruminally (Knight et al., 1975). However attempts to confirm this suggestion by increasing the intake of digestible protein have not produced unequivocal results (Corbett \& Edey, 1977; Davis et al., 1981; Fletcher, 1981). Smith (1985) has reported that short-term changes in either crude protein or digestible energy intake can influence ovulation rate, but for a maximum response increases in both may be required. This finding suggests that increases in ovulation rate in ewes fed lupin grain may be the result of combined increases in post-ruminal protein and digestible energy intake. The present study was therefore undertaken to determine the relative importance of these two components in the response to lupin grain. A preliminary account of this work has been published (Nottle et al., 1985).

\section{Materials and Methods}

Animals and general management. The experiment was conducted during February which is generally considered to be the beginning of the spontaneous breeding season for the Merino ewe in the southern hemisphere (Watson, 1952; Fletcher \& Geytenbeek, 1970). Medium wool parous Merino ewes which had an initial liveweight of $44.8 \pm 0.4 \mathrm{~kg}$ (mean \pm s.e.m.) and condition score (Jefferies, 1961) of $2.69 \pm 0.05$ (mean \pm s.e.m.) were assigned to 5 groups of 40 on the basis of liveweight. Oestrus was synchronized by means of intravaginal progestagen-impregnated sponges (Repromap: Upjohn, Rydalmere, New South Wales) inserted for 12 days. Groups were maintained outdoors in feedlots and fed daily a maintenance ration $(1100 \mathrm{~g})$ of wheaten hay $(1.2 \%$ nitrogen and $9.5 \mathrm{MJ}$ digestible energy/ $\mathrm{kg}$

* Reprint requests to Professor B. P. Setchell. 
dry matter). Ovulation rate was determined using laparoscopy 5-6 days after the second oestrus following sponge removal. Changes in liveweight were determined by weighing groups on the days of sponge removal and endoscopy.

Supplementation. Ewes in 4 groups were given supplements of lupin grain (Lupinus angustifolius, c.v. Uniwhite) or formaldehyde-treated casein and/or wheat starch. These were calculated to supply equivalent amounts of protein post-ruminally and/or digestible energy. The amount of protein supplied post-ruminally and the digestible energy content of the 4 supplements used are given in Table 1. The dry matter digestiblity of the basal ration and the supplements was determined in vitro (Tilley \& Terry, 1963). Crude protein content was determined by micro-Kjeldahl nitrogen $(\times 6 \cdot 25)$. Casein was treated with $4 \%$ formalin at a rate of $100 \mathrm{ml} / \mathrm{kg}$ (Hemsley et al., 1973) to render it as resistant to degradation in the rumen as lupin protein $(\sim 35 \%$; Hume, 1974). The effectiveness of this treatment in increasing the amount of protein digested post-ruminally has been demonstrated previously in nitrogen-retention and wool-growth studies (Hemsley et al., 1973). In the present study, the degradability of the treated casein was checked in vitro (Hemsley et al., 1973) and was found to be similar to that for lupin protein $(37.6 \pm 5 \cdot 3 \%$ and $40 \cdot 6 \pm 6 \cdot 7 \%$, respectively; mean \pm s.e.m., $n=6)$. Part $(30 \%)$ of the maintenance ration was pelleted to incorporate the supplements. Pellets were put out once daily in troughs $(0.5 \mathrm{~m}$ per sheep) for 14 days, starting on Day 4 of the synchronized cycle. Animals were adapted to the supplements by feeding these in increasing amounts for the first 7 days.

Table 1. The digestible energy and post-ruminal protein content of the four supplements

\begin{tabular}{lccc}
\hline Supplement & $\begin{array}{c}\text { Amount } \\
\text { (g/day) }\end{array}$ & $\begin{array}{c}\text { Digestible } \\
\text { energy* } \\
\text { (MJ/day) }\end{array}$ & $\begin{array}{c}\text { Post-ruminal } \\
\text { protein } \dagger \\
\text { (g/day) }\end{array}$ \\
\hline Lupin & 500 & $6 \cdot 3$ & 62 \\
Casein & 160 & $3 \cdot 5$ & 55 \\
Starch & 415 & $6 \cdot 3$ & $<1$ \\
Casein + starch & $160+185$ & $3 \cdot 5+2 \cdot 8$ & $55+<1$ \\
\hline
\end{tabular}

*Calculated from in-vitro dry matter digestibility (MAFF, 1975).

$\nmid$ Crude protein $x$ in-vitro degradability value (see text for details).

Statistical analyses. Changes in liveweight were analysed by one way analysis of variance. Differences in ovulation rate between groups were determined by $\chi^{2}$ tests.

\section{Results}

\section{Liveweight change}

Small increases in liveweight between the days of sponge removal and endoscopy were recorded by all groups (Table 2). There were no significant differences in liveweight gain between the groups.

Table 2. The liveweight change and ovulation rate of control ewes and those fed supplements

\begin{tabular}{|c|c|c|c|c|c|c|}
\hline \multirow[b]{2}{*}{ Treatment } & \multirow{2}{*}{$\begin{array}{c}\text { No. of } \\
\text { ewes }\end{array}$} & \multirow{2}{*}{$\begin{array}{c}\text { Liveweight } \\
\text { change } \\
\text { (g/day) }\end{array}$} & \multicolumn{3}{|c|}{$\begin{array}{c}\text { Ewes with } n \\
\text { ovulations }\end{array}$} & \multirow{2}{*}{$\begin{array}{l}\text { Ovulation } \\
\text { rate }\end{array}$} \\
\hline & & & 0 & 1 & 2 & \\
\hline Control & 40 & $20 \pm 12$ & 2 & 33 & 5 & $1.08 \pm 0.07$ \\
\hline Lupin & 40 & $30 \pm 7$ & 1 & 19 & 20 & $1.48 \pm 0.09^{*}$ \\
\hline Casein & 39 & $28 \pm 13$ & 0 & 21 & 18 & $1.46 \pm 0.08^{*}$ \\
\hline Starch & 40 & $16 \pm 9$ & 4 & 29 & 7 & $1.08 \pm 0.08$ \\
\hline Casein + starch & 40 & $27 \pm 8$ & 2 & 20 & 18 & $1.40 \pm 0.09^{*}$ \\
\hline
\end{tabular}

Values are mean \pm s.e.m.

*Significantly different from control value $(P<0.01)$. 


\section{Ovulation rate}

Supplementation with lupin grain significantly increased ovulation rate by $37 \%$ by increasing the proportion of ewes with two ovulations (Table 2). Similar increases in ovulation rate were recorded by increasing the amount of protein digested post-ruminally in the casein- and casein + starch-supplemented groups. Increasing digestible energy intake separately in the starch supplemented group did not increase ovulation rate.

\section{Discussion}

The present study confirms previous reports that supplementation with lupin grain for the second half of the oestrous cycle can increase ovulation rate in the ewe (Oldham \& Lindsay, 1984; Stewart \& Oldham, 1986). Similar increases in ovulation rate were also mimicked in the present study by feeding casein which had been treated so that its degradation in the rumen was similar to that for lupin protein. This finding confirms previous suggestions that protein intake can influence ovulation rate (Torrell et al., 1973; Davis et al., 1981; Fletcher, 1981) and in particular that responses to lupin grain are initiated by increases in protein digested post-ruminally (Knight et al., 1975). Whether this response is to protein per se or is the result of an increase in the uptake of one or more amino acids remains to be determined. This effect has been described as being threshold in nature (Smith, 1985) with the level at which it occurs dependent on a number of factors including the degradability of the particular protein, previous nutrition and liveweight and the breed of sheep. The exact level of this threshold in the present study is uncertain. However, although wheaten hay is thought to supply sufficient ruminal bacterial protein to meet maintenance requirements (Egan \& Walker, 1975), it would appear from the present results that this amount is unable to 'trigger' increases in ovulation rate, whereas the provision of an extra 50-60 g protein by lupin grain does.

The present study provides no evidence to suggest that the increase in digestible energy intake associated with feeding lupin grain is important in the ovulatory response. Similar results have been reported in comparisons between lupin and cereal grains (Rizzoli et al., 1976; Knight, 1980; Denney, 1983). Smith (1985) has derived equations which predict that the relationship between digestible energy intake and the percentage of ewes with multiple ovulations is continuous. In the present study, there was an apparent increase of $6 \%$ in the percentage of ewes with two ovulations in the starch-supplemented group compared with the control group. This agrees with a predicted value of $5 \%$ from the equation of Smith (1985), confirming that the increase in digestible energy associated with feeding lupin grain is unlikely to be important in the response. Much higher levels of digestible energy intake, however, appear to increase ovulation rate in the short term (Gunn, 1982; Smith, 1985). Whether this effect is mediated via a mechanism similar to that for protein digested post-ruminally cannot be determined from the present study.

It is uncertain whether increases in the amount of protein digested post-ruminally can explain the dynamic effect of flushing as proposed by Coop (1966). However, the existence of a threshold requirement for protein digested post-ruminally, together with the failure to meet this requirement either by increasing the quantity or quality of the food offered, would explain much of the apparent confusion in the literature concerning this effect. Alternatively, failure to demonstrate a flushing response may mean that ewes are already expressing their full genetic potential in terms of ovulation rate because of their previous nutrition, the so-called static or liveweight component of the flushing response (Coop, 1966).

We thank Mr H. B. James, Mr R. S. Norton, Mr B. C. Cowan and the Farm Staff of the Waite Institute for general assistance. M.B.N. was in receipt of a J. S. Davies Postgraduate Studentship. 


\section{References}

Coop, I.E. (1966) The response of ewes to flushing. Wld Rev. Anim. Prod. 2, 69-78.

Corbett, J.C. \& Edey, T.N. (1977) Ovulation in ewes given formaldehyde-treated or untreated casein in maintenance-energy rations. Aust. J. agric. Res. 28, 491-500.

Davis, I.F., Brien, F.D., Findlay, J.K. \& Cumming, I.A. (1981) Interactions between dietary protein, ovulation rate and follicle stimulting hormone in the ewe. Anim. Reprod. Sci. 4, 19-28.

Denney, G.D. (1983) Supplementing Merino ewes at mating for reproductive gain in central western New South Wales. Aust. J. exp. Agric. Anim. Husb. 23, 259-265.

Egan, A.R. \& Walker, D.J. (1975) Resource allocation and ruminant protein production. In Proc. $3 r d$ Wld Conf. Anim. Prod. pp. 551-562. Ed. R. L. Reid. Sydney University Press, Sydney.

Fletcher, I.C. (1981) Effects of energy and protein intake on ovulation rate associated with feeding of lupin grain to Merino ewes. Aust. J. agric. Res. 32, 79-87.

Fletcher, I.C. \& Geytenbeek, P.E. (1970) Seasonal variation in the ovarian activity of Merino ewes. Aust. J. exp. Agric. Anim. Husb. 10, 267-270.

Gunn, R.G. (1982) The influence of nutrition on the reproductive performance of ewes. In Sheep Production, pp. 99-110 Ed. W. Haresign. Butterworths, London.

Hemsley, J.A., Reis, P.J. \& Downes, A.M. (1973) Influence of various formaldehyde treatments on the nutritional value of casein for wool growth. Aust. J. biol. Sci. 26, 961-972.

Hume, I.D. (1974) The proportion of dietary protein escaping degradation in the rumen of sheep fed on various protein concentrates. Aust. J. agric. Res. 25, $155-165$.

Jefferies, B.C. (1961) Body condition scoring and its use in management. Tasm. J. Agric. 32, 19-21.

Knight, T.W. (1980) Effects of liveweight on ovulation rates in Romney ewes. Proc. N.Z. Soc. Anim. Prod. 40, 38-42.
Knight, T.W., Oldham, C.M. \& Lindsay, D.R. (1975) Studies in ovine fertility in agricultural regions in Western Australia: the influence of a supplement of lupins (Lupinus angustifolius c.v. Uniwhite) at joining on the reproductive performance of ewes. Aust. $J$. agric. Res. 26, 567-575.

MAFF (1975) Energy allowances and feeding systems for ruminants. Technical Bulletin No. 33. Ministry of Agriculture, Fisheries and Food. HMSO, London.

Nottle, M.B., Hynd, P.I., Setchell, B.P. \& Seamark, R.F. (1985) Lupin feeding and fecundity in Merinos. Proc. Aust. Soc. Reprod. Biol. 17, 23, Abstr.

Oldham, C.M. \& Lindsay, D.R. (1984) The minimum period of intake of lupin grain required by ewes to increase their ovulation rate when grazing dry summer pasture. In Reproduction in Sheep, pp. 274 276. Eds D. R. Lindsay \& D. T. Pearce. Australian Academy of Science, Canberra.

Rizzoli, D.J., Reeve, J.L., Baxter, R.W. \& Cumming, I.A. (1976) The effect of lupin grain supplementation on ovulation rate in Border Leicester $\times$ Merino ewes $J$. Reprod. Fert. 46, 518.

Smith, J.F. (1985) Protein, energy and ovulation rate. In The Genetics of Reproduction in Sheep, pp. 349-359. Eds R. B. Land \& D. W. Robinson. Butterworths, London.

Stewart, R. \& Oldham, C.M. (1986) Feeding lupins for four days during the luteal phase can increase ovulation rate. Proc. Aust. Soc. Anim. Prod. 16, 367-370.

Tilley, J.M.A. \& Terry, R.A. (1963) A two stage technique for the in vitro digestion of forage crops. J. Br. Grasl. Soc. 18, 104-111.

Torrell, D.T., Hume, I.D. \& Weir, W.C. (1973) Effect of protein and energy during flushing on lambing performance of range ewes. J. Anim. Sci. 34, 479-482.

Watson, R.H. (1952) Seasonal variation in reproductive activity in ewes. Aust. vet. $J .28,1-5$.

Received 22 March 1988 